\title{
Gifted and Talented Students' Views about Biology Activities in a Science and Art Center
}

\author{
Murat Özarslan ${ }^{1 *}$, Gülcan Çetin² \\ ${ }^{1}$ Biology Teacher, Ministry of National Education, Kocaeli, Turkey, ${ }^{2}$ Department of Mathematics and Science Education, Biology Education, Ballkesir \\ University, Balıkesir, Turkey
}

*Corresponding Author: muratozarslan14@gmail.com

\section{ABSTRACT}

The aim of the study was to determine gifted and talented students' views about biology activities in a science and art center. The study was conducted with 26 gifted and talented students who studied at a science and art center in southwestern Turkey. Students studied animal and plant genus and species in biology activities. Data were collected through a questionnaire. Data were analyzed using descriptive and content analyses methods. The research results revealed that the students had a great interest in the animals and plants, which they could not see nor examine closely in their own daily life. Since they found the activities enjoyable, interesting, and exciting, they liked biology courses much more. The results are discussed in terms of the education of the gifted and talented students.

KEY WORDS: gifted and talented students; science and art center; biology activities; animals and plants

\section{INTRODUCTION}

B iology makes a big contribution to our understanding of nature, and therefore, causes radical changes in social life. Students have an opportunity to use and apply this understanding and information about biology in society, environment, industry, agriculture, health, technology, and their own lives (MoNE Biology Course Curriculum, 2013). In science courses, especially in biology courses, students gain the habit of giving the right decision and thinking objectively in the face of events and situations by examining their environment through scientific methods (Korkmaz and Kaptan, 2001).

The main criticisms on the teaching of science in Turkey are as follows: The quite limited relationship between the out of school lives of students and teaching of science, inadequate level of equipment usage in classes, and inadequate level of science activity participation of students (Y1lmaz and Türkmen, 2007). Therefore, the ability of students to use in real life what they have learned in science classes and the benefits of this would bring to their lives more active participation of students in science activities and preparation of a more authentic learning environment with the use of class materials which are suitable for science subjects is very important for teaching of science.

Science, especially biology, has been reported to be one of the basic interest areas for many gifted and talented students (Van Tassel-Baska and Stambaugh, 2009). Gifted and talented students are individuals that perform at a high level in terms of specific academic fields or intelligence, creativity, art, and leadership capacity (Freeman, 1999; MoNE Science and Art Center Guideline, 2015; Trna, 2014). Hidi and Renninger (2006) stated that gifted and talented students are more curious and active in classes when they study in their favorite areas, and therefore, do their assignments more willingly. Furthermore, Trna (2014) stated that gifted and talented students are not pleased with memorizing, being asked a lot of questions having unusual ideas, developing new solutions for problems, or establishing meaningful relationships between things which seem unrelated.

Gifted and talented students are quite interested in science, and they have a strong desire to have high degrees. Thus, gifted and talented students are willing to do research, put forward new inventions in science especially in biology, and fulfill independent projects (Özarslan, 2015; Van Tassel-Baska and Stambaugh, 2009) It has been noted that some of these students build their own laboratories in their houses to reach their aims. (Gökdere, 2004; Van Tassel-Baska and Stambaugh, 2009). When gifted and talented students observe their new products and the results of their research in science, students' interest in science increases more and more (Çepni et al., 2002). Gifted and talented students give more importance to the subjects in which they have an interest, some even doing extra assignments beyond those given to them by their teachers (Sak, 2012).

Gifted and talented students form a separate group since they have different development and learning attributes in comparison with their peers. Therefore, characteristics and needs unique to gifted and talented students must be identified, and training must be optimized based on these properties. In other words, specialization in education and making new educational arrangements, which are in compliance with students' learning rate, interests, and capabilities will fulfill the special learning in accordance with characteristics and needs of these students and also will make the education process 
more effective and productive. Regarding this issue, teachers of gifted and talented students must identify the interests of the students using various interest inventories and must develop teaching activities in line with the interest types. In addition, students must be given the right to choose class activities (Sak, 2012). In this way, it has been argued that gifted and talented children are better able to succeed; their abilities and potential better recognized and developed; and their development progressing more smoothly (Kontaş, 2010, Kontaş and Yağc1, 2016; Kök, 2012; Palanc1, 2004; Uzun, 2004). To make these arrangements, students' interests, curiosities, and needs must be identified in the education process of gifted and talented students; sources of motivation and success must be revealed; necessary learning strategies need to be decided, and detailed work should be completed to develop these situations (Baykoç and Kurt, 2004). Otherwise, it has been noted that these students' potential was not used to its highest level; their talent decreased; and their talent actually disappeared over time as their needs in education were not fulfilled, or there was an inadequate fulfillment (Kök, 2012). Moreover, these students may not only get bored with education but also their interest and curiosity may decrease eventually.

As a result, in Turkey education of gifted and talented students is implemented in Science and Art Centers (SACs) along with their formal education. These centers aim to raise awareness about the individual talents for the school-age gifted and talented students and want to help students develop their capacity and use it at its highest level (Gökdere and Küçük, 2003). In these centers, developing potential talents of the gifted and talented students through various effective activities is the main aim (Gökdere and Ayvacı, 2004; Gökdere and Küçük, 2003). In SACs, gifted and talented students complete adaptation, support training, raising awareness about individual talents, special talent development, and project production programs. In the special talent development program, it is the target that these students should be aware of their individual interests and talents as well as they should acquire knowledge, skills, and behaviors with discipline in-depth or at an advanced level. Whereas in the project production program, project production works are conducted as individual work or group work in accordance with gifted and talented students' interests, talents and preferences (MoNE Science and Art Center Guideline, 2015).

The fact that gifted and talented students may easily get bored in endeavors which are repetitive, easy, or excessively challenging and require extended periods of time and see these as unnecessary wastes of time has been established. On the other hand, it is stated that these students are happy and motivated by conducting activities which are beneficial to their everyday lives, personal interests, curiosity and desires, needs of the society, career goals, to their own persons and to humanity (Gökdere and Küçük, 2003; Powers, 2008; Sak, 2012; Taber, 2010; Ngoi and Vondracek, 2004).

It is very important for the gifted and talented students to take education in accordance with their own interests and talents
(Sak, 2012). In this study, interest is a tendency of curiosity, importance, inclination, fondness, liking, and getting involved in a specific event, object or thought. When students deal with what they have an interested, they become happier and they gather information more in-depth about the objects and events in which they take are interested. Moreover, interest has an important effect on the future planning and development of the students (Erten, 2008).

Hırça (2012) stated that programs and various scientific activities, which were carried out in touch with nature, would contribute to the development of the talents and skills, which gifted and talented students needed. Whereas Emre (2012) and Emre and Erten (2012) put forward that 5-8 ${ }^{\text {th }}$-Grade non-gifted students were interested in the subjects such as the importance of the plants in nutrition, their development, reproduction, and spread. However, these students did not give any attention to ornamental plant care and the kind of flowers in the school garden and their own gardens. On the other hand, students wanted to get information about animals, play with an animal, and take care of an animal and its feeding. However, students were not eager to learn whether the body structures and behaviors of animals living in the zoo were different from the ones living in the wild. In addition to these, it was stated that students had a stronger interest in animals than plants and it was also stated that interesting subjects in science courses, students' liking of the plants and animals and practices such as nature excursions and scientific journal subscriptions had an effect on the students' interest and curiosity about animals and plants. Yetkin (1998) reported that gifted and talented students gained a different viewpoint about animals and plants; they started to love animals and overcome their fear of animals such as snakes, caterpillars, worms, and insects, and these students developed a positive attitude toward the natural life thanks to the biology education. When related literature is reviewed, we encounter the studies that aim to identify interests (Emre, 2012; Emre and Erten, 2012), attitudes and views of non-gifted students about animal and plant species (Özel et al., 2013; Prokop and Tunnicliffe, 2008; Prokop et al., 2008). However, there was no study that aims to indicate gifted and talented students' interest, attitude, and opinions about animal and plant species and their opinions about biology lessons related to animals and plants. Therefore, it is thought that indicating the opinions of gifted and talented students about SAC biology activities SAC will have great impact on improving and differentiating the activities according to the interest and passion of gifted and talented students.

\section{METHOD}

This study is descriptive in nature, and qualitative research methodology was applied to address the research question (Büyüköztürk et al., 2013).

\section{Problem}

What were the gifted and talented students' views about SAC biology activities? 


\section{Study Group}

A study group included 26 gifted and talented students who were chosen from 85 gifted and talented students in a SAC in southwestern Turkey in the spring semester of the 2012-2013 academic years. The SAC has more than 10 years of experience in the fields of physics, chemistry, history, painting, music, etc. This study's group consisted of 26 gifted and talented students (11 female and 15 male students aged 11-13) who studied for special talent development and project production programs in the field of biology. They were chosen for the field of biology according to their willing, interests, ability, and talents. The study group was selected in accordance with criterion sampling method, which is one of the purposeful sampling methods (Büyüköztürk et al., 2013). After necessary permission was taken from the SAC, all 26 volunteer students filled out a questionnaire.

\section{Biology Activities Carried out in the Science and Art Center} Biology activities related to animal and plant genus and species have been carried out for 2 years in the SAC. The study consisted of the gifted and talented students who participated in almost all of these activities continuously and took part in the special talent development and project production programs. In the activities, it was the aim that the gifted and talented students would recognize and comprehend the features of animal and plant genus and species. For instance, when a living animal was brought to class, students and the teacher together prepared an appropriate habitat for the animal and the students took the responsibility of meeting the basic needs of the animal. The gifted and talented students sometimes took care of some animal and plant genus and species in the laboratory or at their own houses for a short-term and in turns when they obtained permission from their families. Instruments, which may be visual and a source of information, such as Internet, books, photos of this genus and species, and presentation are used for examining them in laboratories in detail. Moreover, teachers and students took photos of them and students saw and examined them in detail on a large visual screen with the help of the photos.

The biology activities were planned and carried out with three teachers, one of whom works in the SAC, under the consultancy of a teacher who has a doctorate in the field of biology on animals. For instance, the subject of cryptogams was planned and carried out monthly. The specialist teacher sometimes did a field study out of town and introduced the living beings that he had found or taken photos. The living things that can be found in the immediate environment or the ones that the gifted and talented students wanted to examine may be included in the activities. Sometimes students' parents or fishermen brought some fish and animals to the SAC. For instance, a shark caught by the fishermen was brought to class and examined in the class or students fed a snake, which they caught on an excursion, in class for months and examined it. Parents were very effective in this matter. For instance, when a parent went hunting, he brought a partridge, an animal that the students had an interest into it in the SAC.
A list of the animal and plant genus and species examined in biology activities in the SAC is presented in Appendix 1. In the activities, animals and plants were taught to students in terms of genus or species. The number of the living species changed with regard to the activity. The living beings were examined as single or dual, and the number of the plant genus and species may be more than that of animal genus and species. Activities were mostly performed in groups. The number of the students in groups differs: $3-5,8-10$ or more students can join a group. Biology activities were arranged as $80 \min (2$ class hours) weekly.

Teachers wanted the students to diagnose the animal and plant genus and species in biology activities with the help of the genus and species identification key. After the biology activity, question and answer part followed and lastly a study report was written. In the report, students were asked to write systematic of the genus and species diagnosed in the biology activity and to draw the shape and point the important features on the shape. During reporting process, teachers reminded students of the important features of these living beings or students asked to explain what they had in mind about examined genus and species through a method they preferred to use (pictures, cartoons, stories, etc.).

\section{Data Collection and Data Analyses}

In the study, the questionnaire of Gifted and Talented Students' Views about Biology Activities was used as a data collection tool (Appendix 2). The questionnaire consisted of 10 openended questions prepared by the researchers to reveal students' interests and views about animal and plant genus and species, which they examined in biology activities.

A pilot study was conducted with five gifted and talented students who participated in biology activities at the same SAC. After the pilot study, some questions were revised by the researchers. The final version of the questionnaire was offered to this study's 26 gifted and talented students.

Data were analyzed using descriptive and content analyses. Similar statements were categorized into specific theme and sub-themes. These statements were classified and interpreted for the readers to understand them easily (Yıldırım and Şimşek, 2008). In codification, data were read line-by-line without a theoretical basis, and important points in line with the aim of the research were established (Strauss and Corbin, 1990; Yıldırım and Şimşek, 2008). In other words, data were revised many times, and short notes were taken about codifications. Statements related to each question were categorized into themes and then sub-themes. After coding, categories were compared, and the similarities and differences were discussed. In line with the similarities and shared decisions of the researchers, codifications of themes and sub-themes were finalized. The percentages of these codifications were determined, and tables were created.

The internal consistency of theme and sub-theme categories was provided by this paper's authors. This was achieved by 
constant controls of the codifications by the researchers until they were in agreement on categories in every table (Miles and Huberman, 1994; Özdinç and Altun, 2014; Türnüklü, 2000). The rank of animal and plant genus and species in living things in each table was checked by a professor who studies on plants and another professor who studies on animals in Balıkesir University in Turkey. Moreover, the significant points in students' explanations were quoted, and a student number such as $\mathrm{S} 5$ is given.

\section{RESULTS}

Table 1 presents findings related to the animal and plant genus and species which the gifted and talented students claimed to have examined in biology activities in the SAC.

Table 1 highlights that the students mostly examined earthworm (2\%) from Annelida, snail (1\%) from Mollusca, and sea urchin $(3 \%)$ from Echinodermata and the majority of the students examined scorpion (15\%) from Arthropoda among invertebrates in the animal kingdom. Students claimed to have examined shark $(6 \%)$ from Chondrichthyes, scorpionfish (2\%) from Osteichthyes, newt (10\%) from Amphibians, snake (16\%) from Reptiles, and interesting birds (3\%) from Class Aves among vertebrates in the animal kingdom. In the Plant Kingdom, it was thought that Cryptogams, especially fern $(31 \%)$, were mostly examined plants whereas pine tree (8\%) from Gymnosperms and chamomile (4\%), and dill (4\%) from Angiosperms were examined among the Phanerogams.

Some examples of the views of the gifted and talented students were:

We examined lizard, scorpion, chameleon, salamander, snake, spider, scorpion fish, fern and also pine tree. (S14)

We studied shark, starfish, sea urchin, daisies, tangerine, dill, pulmonaria officinalis. (S3)

In the activities, we also analyzed thornback, wiggler, snail and frog. (S6)

In Table 2, the animal and plant genus and species that most attracted the attention of gifted and talented students in biology activities are reported.

According to Table 2, the students stated that the animals that most attracted their attention were Earthworm (2\%) from Annelida, sea urchin (1\%) from Echinodermata, and scorpion $(19 \%)$ from Arthropoda in Invertebrates in Animal Kingdom. It is seen that students have an interest in shark (5\%) from Chondrichthyes, newt (12\%) from Amphibians, snake (19\%) from Reptiles, and Birds (4\%) from Class Aves in Vertebrates. It is seen that students mostly had an interest in fern (23\%) in Cryptogams whereas they had an interest in pine tree $(10 \%)$ from Gymnosperms and dill (4\%) from Angiosperms in Phanerogams in Plant Kingdom.

Some opinions of the gifted and talented students were:

In the activities, snake, salamander, frog, shark and duck took my attention most. (S22)

\begin{tabular}{|c|c|c|}
\hline Kingdom & Animal and plant genus and species & $\%$ \\
\hline \multicolumn{3}{|l|}{ Animal Kingdom } \\
\hline \multicolumn{3}{|l|}{ Invertebrates } \\
\hline Annelida & Earthworm & 2 \\
\hline Mollusca & Snail & 1 \\
\hline \multirow[t]{6}{*}{ Arthropoda } & Scorpion & 15 \\
\hline & $\mathrm{Crab}$ & 5 \\
\hline & Spider & 4 \\
\hline & Insect, Butterfly & 6 \\
\hline & Pillbug & 1 \\
\hline & Centipede & 1 \\
\hline \multirow[t]{2}{*}{ Echinodermata } & Sea urchin & 3 \\
\hline & Starfish & 2 \\
\hline \multicolumn{3}{|l|}{ Vertebrates } \\
\hline \multirow[t]{2}{*}{ Chondrichthyes } & Shark & 6 \\
\hline & Ray & 1 \\
\hline \multirow[t]{2}{*}{ Osteichthyes } & Scorpion fish & 2 \\
\hline & Bonito & 1 \\
\hline \multirow[t]{2}{*}{ Amphibians } & Newt & 10 \\
\hline & Frog & 5 \\
\hline \multirow[t]{4}{*}{ Reptiles } & Snake & 16 \\
\hline & Lizard & 10 \\
\hline & Turtle & 9 \\
\hline & Chameleon & 6 \\
\hline \multirow[t]{2}{*}{ Birds } & Interesting birds & 3 \\
\hline & Duck & 1 \\
\hline \multicolumn{3}{|l|}{ Plant Kingdom } \\
\hline \multirow[t]{5}{*}{ Cryptogams } & Fern & \\
\hline & & 31 \\
\hline & Lungwort & 18 \\
\hline & Moss & 12 \\
\hline & Marsh horsetail & 4 \\
\hline \multicolumn{3}{|l|}{ Phanerogams } \\
\hline \multirow[t]{2}{*}{ Gymnosperms } & Pine tree & 8 \\
\hline & Fir & 2 \\
\hline \multirow[t]{6}{*}{ Angiosperms } & Chamomile & 4 \\
\hline & Dill & 4 \\
\hline & Tangerine & 2 \\
\hline & Rubber tree & 2 \\
\hline & Corn poppy & 2 \\
\hline & Snapdragon & 2 \\
\hline
\end{tabular}

Fern, dill, grass, shark and chameleon are the most attractive living beings for me. (S11)

Scorpion, lizard, centipede and sea urchin took my attention. (S21)

Table 3 highlights the most interesting features of animal and plant genus and species.

According to Table 3, the students mostly regarded the following as the most interesting features: The fact that animals were venomous (22\%); structural features of snakes 


\begin{tabular}{|c|c|c|}
\hline Kingdom & Animal and plant genus and species & $\%$ \\
\hline \multicolumn{3}{|l|}{ Animal Kingdom } \\
\hline \multicolumn{3}{|l|}{ Invertebrates } \\
\hline Annelida & Earthworm & 2 \\
\hline \multirow[t]{5}{*}{ Arthropoda } & Scorpion & 19 \\
\hline & Crab & 3 \\
\hline & Spider & 3 \\
\hline & Insect, Butterfly & 4 \\
\hline & Centipede & 1 \\
\hline Echinodermata & Sea urchin & 1 \\
\hline \multicolumn{3}{|l|}{ Vertebrates } \\
\hline Chondrichthyes & Shark & 5 \\
\hline \multirow[t]{2}{*}{ Osteichthyes } & Scorpionfish & 2 \\
\hline & Fish & 1 \\
\hline \multirow[t]{2}{*}{ Amphibians } & Newt & 12 \\
\hline & Frog & 5 \\
\hline \multirow[t]{4}{*}{ Reptiles } & Snake & 19 \\
\hline & Lizard & 10 \\
\hline & Chameleon & 6 \\
\hline & Turtle & 4 \\
\hline Birds & Birds & 4 \\
\hline \multicolumn{3}{|l|}{ Plant Kingdom } \\
\hline \multirow[t]{4}{*}{ Cryptogams } & Fern & 23 \\
\hline & Lungwort & 18 \\
\hline & Moss & 15 \\
\hline & Marsh horsetail & 8 \\
\hline \multicolumn{3}{|l|}{ Phanerogams } \\
\hline Gymnosperms & Pine tree & 10 \\
\hline \multirow[t]{6}{*}{ Angiosperms } & Dill & 4 \\
\hline & Grass & 2 \\
\hline & Corn poppy & 2 \\
\hline & Tangerine & 2 \\
\hline & Rubber tree & 2 \\
\hline & Chamomile & 1 \\
\hline
\end{tabular}

such as head, mouth, tongue, scales (17\%), and features and reproduction of lungwort $(21 \%)$ and fern $(21 \%)$.

Some of the explanations of the gifted and talented students were:

Especially the poison of snake and scorpion took my attention. (S7)

Ifound very interesting that poisonous snakes have triangle heads and acid glands. (S13)

The way how lungwort propagates took my attention because they leave their spores in the water. (S20)

It is interesting that mosses are able to have both sexual reproduction and also asexual generation. (S11)

The pattern of shark scales is very interesting (S8).

Table 4 presents the animal and plant genus and species, which the gifted and talented students wanted to examine in biology activities in the SAC.
Table 4 shows that the students mostly wanted to examine tarantula (1\%) and eyes of the flies (1\%) from Arthropoda and cuttlefish (1\%) from Mollusca among invertebrates in the animal kingdom whereas students mostly wanted to examine shark (4\%) from Chondrichthyes; frog (2\%) from Amphibians; snake $(3 \%)$ and lizard (3\%) from Reptiles; peacock $(1 \%)$, eagle (1\%), and seagull (1\%) from Class Aves; giraffe (2\%), mole $(2 \%)$, lion $(2 \%)$, and bear $(2 \%)$ from Mammals among Vertebrates. Most of the students wanted to examine mosses (2\%) among Cryptogams and carnivorous plants (6\%) from Angiosperms among Phanerogams. Students mentioned that they wanted to examine terrifying animals (1\%) and newly discovered species (1\%). However, some students stated that they did not find plant species interesting (3\%).

Some of the opinions of gifted and talented students were: I would like to analyze different kinds of snakes. (S9)

I want to study on white sharks. (S19)

I would like to analyze carnivores they may take my attention. (S16)

I want to investigate the eyes of snakes. (S23).

Table 5 presents the gifted and talented students' feelings and views about the biology activities in which animal and plant genus and species were examined.

According to Table 5, most of the gifted and talented students stated that they found the biology activities quite enjoyable, amusing, pleasing, and exciting (41\%) and very good, nice, and interesting (32\%). However, a few students found the biology activities boring (5\%).

Some views of the gifted and talented students:

While examining animals, Ifeel very excited and happy. (S25) As I am very curious about animals and plants, activities are very entertaining for me. (S7) Activities are a bit boring (S26).

When the reasons of gifted and talented students' positive feelings and thoughts related to biology activities concerning animal and plant species were analyzed, The gifted and talented students had positive feelings and thoughts about biology activities related to animal and plant species. Some students mentioned that they saw and inspected unfamiliar and interesting animals (7\%) while some of them stated that their teachers allowed them to touch the animals (2\%).

The findings concerning how the biology activities impacted on the gifted and talented students' feeling and thoughts are presented in Table 6.

As seen in Table 6, most of the students had positive feelings and views about biology such as an increase in their interest and liking level and also they looked forward to attending the courses $(36 \%)$ as they had positive impressions (34\%).

Two examples of students' feeling and thoughts are: Many animals and plants are brought to the activities. Thus, I am looking forward to attending classes. (Ö13)

My interest, love and curious about the lesson has increased. (Ö2). 
Table 3: Percentages of themes and sub-themes of most interesting features of animal and plant genus and species for the gifted and talented students in biology activities in the SAC

\begin{tabular}{|c|c|c|}
\hline Theme & Sub-theme & $\%$ \\
\hline \multirow[t]{15}{*}{ Interesting features of animal genus and species } & Venomousness & 22 \\
\hline & Structural features of snakes such as head, mouth, tongue, and scales & 17 \\
\hline & Structural features of scorpions such as venomous sting or mouth & 10 \\
\hline & Slow movement and color change of chameleon & 7 \\
\hline & The fact that snakes are submissive and harmless & 7 \\
\hline & Gender differences and wet skins of newts & 7 \\
\hline & Structural features of scorpionfish & 5 \\
\hline & Different eye structures of animals & 5 \\
\hline & Aggression & 2 \\
\hline & Nutrition of Anatolian yellow scorpion & 2 \\
\hline & Color and species of frogs & 2 \\
\hline & Scale structure of shark & 2 \\
\hline & Internal organs of birds & 2 \\
\hline & Color change of Anatolian Lizard in the mating season. & 2 \\
\hline & Fast movement of lizard. & 2 \\
\hline \multirow[t]{8}{*}{ Interesting features of plant genus and species } & Features of lungwort and its reproduction & 21 \\
\hline & Features of fern and its reproduction & 21 \\
\hline & Reproduction of mosses & 16 \\
\hline & Shape of marsh horsetail and the fact that it is used in tea-making. & 11 \\
\hline & Structure of pine trees and their reproduction & 11 \\
\hline & Root of chamomile and its reproduction & 5 \\
\hline & Shape of corn poppy & 5 \\
\hline & They do not attract my attention. & 5 \\
\hline
\end{tabular}

\section{DISCUSSION AND CONCLUSION}

The following are the animal and plant genus and species which the gifted and talented students claimed to have examined in biology activities in the SAC: Earthworm, snail, sea urchin, and scorpion among Invertebrates: Shark, newt, snake, and birds among Vertebrates. It was observed that mostly ferns from Cryptogams were examined whereas mostly pine trees, chamomiles, and dills from Phanerogams were examined among the Plant Kingdom. According to these conclusions, it can be seen that many different kinds of living things were included in the SAC's biology activities. This situation is very useful to improve biology activities in accordance with the interest and curiosity of the students. Thanks to these activities, students were able to both have detailed information about living things which they were curious about, and they will know the environment better, and their awareness level will increase.

The gifted and talented students could not answer the question which animals were examined at the species level. For instance, although students examined Anatolian snake, Caspian Whip snake, and Whip snake, it was seen that they only had a general idea about snakes at the genus level when they wrote the species of living beings they examined. This finding suggested that students did not notice the details that helped them distinguish animal and plant species. Among the reasons for this situation are that students identified a living being as a snake or they did not identify it at species level because this required a more systematic identification than the genus level. Adequate assessment and evaluation practices may not have been used in these activities. According to these conclusions, the level the students reached in biology activities should be indicated with the help of appropriate assessment evaluation methods so that the incorrect or gaps in the students' knowledge should be revised again and some feedback needs to be given. In addition, biology activities could be enriched with some worksheets, riddles, and puzzles.

The following are the animal genus and species that mostly attracted the attention of the gifted and talented students in biology activities in the SAC: Earthworm, sea urchin, and scorpion among invertebrates and shark, newt, snake, and birds among Vertebrates whereas the followings are the plant genus and species that most attracted the attention of the gifted and talented students: Fern from Cryptogams; pine tree and dill from Phanerogams. It was observed that there were many similarities between animal and plant genus species students claimed to have examined in biology activities in the SAC, and animal and plant genus and species that most attracted the attention of the students. The congruence of the findings is important because it was thought that the gifted and talented students would remember the animal and plant genus and species that attracted their attention the most. The statement of Laçin and Nuhoğlu (2009) supported that students succeed in 


\begin{tabular}{|c|c|c|}
\hline Kingdom & Animal and plant genus and species & $\%$ \\
\hline \multicolumn{3}{|l|}{ Animal Kingdom } \\
\hline \multicolumn{3}{|l|}{ Invertebrates } \\
\hline Mollusca & Cuttlefish & 1 \\
\hline \multirow[t]{2}{*}{ Arthropoda } & Fly & 1 \\
\hline & Tarantula & 1 \\
\hline \multicolumn{3}{|l|}{ Vertebrates } \\
\hline Chondrichthyes & Shark & 4 \\
\hline \multirow[t]{2}{*}{ Osteichthyes } & Blowfish & 1 \\
\hline & European anchovy & 1 \\
\hline Amphibians & Frog & 2 \\
\hline \multirow[t]{4}{*}{ Reptiles } & Snake & 3 \\
\hline & Lizard & 3 \\
\hline & Turtle & 2 \\
\hline & Chameleon & 1 \\
\hline \multirow[t]{3}{*}{ Birds } & Peacock & 1 \\
\hline & Eagle & 1 \\
\hline & Gull & 1 \\
\hline \multirow[t]{10}{*}{ Mammals } & Giraffe & 2 \\
\hline & Mole & 2 \\
\hline & Lion & 2 \\
\hline & Bear & 2 \\
\hline & Monkey & 1 \\
\hline & Dolphin & 1 \\
\hline & Marten & 1 \\
\hline & Whale & 1 \\
\hline & Bat & 1 \\
\hline & Rabbit & 1 \\
\hline \multirow[t]{2}{*}{ Others } & Terrifying animals & 1 \\
\hline & Newly discovered species & 1 \\
\hline \multicolumn{3}{|l|}{ Plant Kingdom } \\
\hline \multirow[t]{2}{*}{ Cryptogams } & Mosses & 2 \\
\hline & Fern & 1 \\
\hline \multicolumn{3}{|l|}{ Phanerogams } \\
\hline Gymnosperms & Pine cone & 1 \\
\hline \multirow[t]{12}{*}{ Angiosperms } & Carnivorous plants & 6 \\
\hline & Rose & 2 \\
\hline & Bamboo & 2 \\
\hline & Oak tree & 1 \\
\hline & Coconut & 1 \\
\hline & Water lily & 1 \\
\hline & Purslane & 1 \\
\hline & Dill & 1 \\
\hline & Banana & 1 \\
\hline & Ivy & 1 \\
\hline & Four-leaf clover & 1 \\
\hline & Spiderwort & 1 \\
\hline \multirow[t]{2}{*}{ Others } & Poinsettia & 1 \\
\hline & Flowers & 3 \\
\hline
\end{tabular}

the lessons in which they take an interest and what they have learned becomes more permanent. Moreover, the gifted and talented students mostly gave importance to Arthropoda and reptiles whereas they were interested in Cryptogams among plant genus and species. The idea that incomplete knowledge, misconceptions, beliefs, and fears which students formerly had about the animal genus and species in biology activities changed in a positive way during the activity process can be considered as the reason for their great interest in Arthropoda and reptiles. Since in their research Oluk (2009) and Prokop and Tunnicliffe (2008) stated that students had incomplete knowledge and many misconceptions about snakes and spiders, they had negative attitudes toward snakes and spiders, and they were afraid of snakes.

The differences between plants species and flowering plants and the fact that these differences attracted the attention of the students may be viewed as the reason for the increase in the interest of students for Cryptogams. It was thought that the gifted and talented students were very eager and curious about the innovations and research in science (Gökdere, 2004) and thereby these students showed greater interest in the different features of animal genus and species. Accordingly, first of all, the interest, desire, and curiosity of the gifted and talented students in biology activities should be determined. Next, these activities should be organized in accordance with the interest of students. However, topics or living things that the students were familiar with or have already known about in detail ought not to be used. Otherwise, the students might get bored, and they may not want to continue to the classes.

With the data related to the most interesting features of plants and animals that the gifted and talented students examined, it was seen that these students regarded the most interesting features as the structural features such as head, mouth, tongue, and scales of snakes, and the fact that animal genus and species were mostly venomous whereas the features and reproduction of lungwort and fern were regarded as the most interesting features among plant genus and species. These results show that students may have a great interest in such subjects as snakes and venomousness which they did not have any experience in their real lives or they could not see in their immediate environment and examine closely because nongifted students are not eager to learn about the body structures of domestic animals and whether or not the behaviors of the animals living at the zoo are different from the ones living in the wild (Emre, 2012; Emre and Erten, 2012). In other words, students did not take much interest in the subjects that they experienced in their lives. On the other hand, the gifted and talented students have the greatest interest in the features and reproduction of lungwort and fern among cryptogams since these plants differed from Phanerogams, which the gifted and talented students frequently saw in their immediate environment in terms of their features. Emre (2012) and Emre and Erten (2012) mentioned that non-gifted students wanted to learn what a plant needed to grow, how the plants reproduced and spread. The findings of the study showed that the gifted and talented students wanted to learn similar subjects on plant genus and species; however, they showed greater interest in plant genus and species that had different features.

When the results related to the animal and plant genus and 
Table 5: Percentages of themes and sub-themes of the gifted and talented students' feelings and views about the animal and plant genus and species in biology activities in the SAC

\begin{tabular}{lll}
\hline Theme & Sub-theme & $\%$ \\
\hline+ & Very enjoyable and amusing/Pleasing/Exciting & 41 \\
& Very good/A nice practice/Interesting & 32 \\
- & Informative and educational & 7 \\
& Boring & 5 \\
Reasons for positive feelings and views & Disgusting & 7 \\
& I saw and examined interesting animals which I do not see normally & 2 \\
& Our teachers allowed us to touch the animals & 2 \\
\hline
\end{tabular}

\begin{tabular}{|c|c|c|}
\hline Theme & Sub-theme & $\%$ \\
\hline \multirow[t]{5}{*}{ Impact } & $\begin{array}{l}\text { Increase in interest/They like } \\
\text { the lessons more/They look } \\
\text { forward to attending the lessons }\end{array}$ & 36 \\
\hline & Have positive impressions & 34 \\
\hline & More enjoyable & 15 \\
\hline & More comprehensible & 3 \\
\hline & Learning a lot of things & 3 \\
\hline
\end{tabular}

species which the gifted and talented students wanted to examine in biology activities in the SAC were analyzed, it was found that the students mostly wanted to examine tarantula, cuttlefish, shark, frog, snake, lizard, peacock, eagle, gull, giraffe, mole, lion, bear, and the eyes of flies in the animal kingdom whereas it was found that they mostly wanted to examine mosses among Cryptogams and carnivorous plants from Angiosperms among Phanerogams. As it can be seen, students mostly wanted to examine, and they were interested in the animals that they could not see in their immediate environment and examine. The fact that mosses and carnivorous plants differed from plant species in the immediate environment of the students may be regarded as the reason why students wanted to examine these species in biology activities. However, it was found out that some students did not find plant species interesting. There are similarities between these results and the findings that students did not give any attention in the subjects such as ornamental plant care and the kind of flowers in the school garden and in their own gardens and they did not show interest in plant species which they could see in their immediate environment and examine (Emre, 2012; Emre and Erten, 2012). These results showed that students took less interest in animal and plant genus and species that they could observe in their immediate environment and examine whereas the gifted and talented students were generally more interested in animal and plant genus and species, which had different features, and they could not observe in their immediate environment. Therefore, it is thought if necessary importance is given to these points in biology activities, it will contribute to the gifted and talented students' interest and curiosity about the activities. Furthermore, it can supply gifted and talented students with improving different aspects toward nature, increasing their awareness level and approaching to environment and nature more judgmentally.

When the findings related to the feelings and views of the gifted and talented students about the biology activities, in which animal and plant genus and species were examined, were analyzed, it was found that most of the students stated the biology activities were very enjoyable, amusing, pleasing, exciting and very good, nice, and interesting. According to some students, the reason for this situation was that they had a chance to see, touch and examine interesting animals, which they did not see in normal life. When the results related to the effect of the biology activities on feelings and views about the field of biology were analyzed, it was discovered that most of the gifted and talented students showed more interest in biology, liked biology more, and looked forward to attending biology courses. In addition, they thought that biology was more enjoyable and more comprehensible. Research shows that students' motivation for the lessons will increase when science teachers organize class activities by considering students' interests and curiosities (Emre and Erten, 2012). Therefore, the use of animals and plants that attract the attention of the students may increase students' interests, curiosities, and motivation. With this way, gifted and talented students will be able to continue to the classes without feeling bored.

Ultimately, the description of gifted and talented students' interests and the organization of the activities in accordance with their interest will be helpful to make these students' education different according to their needs. With this way, not only the decrease of the students' interest, curious and desire toward biology will be prevented but also their interests and curious level will increase. In addition to this, it will provide gifted and talented students to learn the topics better, and in detail and at this point, it will make them easier feel the emotional satisfaction. In biology activities, taking the livings into the lesson which the students did not have any chance to meet or have not got enough detailed information about will increase their awareness of nature and environment. Thus, the students will adopt more judgmental and analyst aspect toward nature and environment. 
Therefore, with the help of SAC biology activities, students will be able to attend productive and rich classes actively. They will have correct information about the living things the students lack information about or have inadequate knowledge and negative attitudes about in their life. Moreover, they will be able to improve positive opinions about them. The usage of information that students have learned in real life will increase in daily life. In conclusion, it will be possible to reach the aims of biology teaching.

The following suggestions can be made within the frame of these results of the study:

- The number of biology-related activities should be increased in the SACs.

- Since the assessment and evaluation instruments implemented in biology activities in the SAC are inadequate, it would be beneficial for the success of the activities if the assessment and evaluation instruments were corrected.

- Teachers of gifted and talented students need to identify the interests of the students using various interest inventories before teaching (Sak, 2012).

- Genus and species that attract the attention of the students must be chosen for the activities when the biology activities are prepared.

- Students' interest in animals and plants should be supported because this will enable students to love and protect nature.

- Identifying the subjects in which gifted and talented students have an interest will enable students to participate in the activities more actively. This will keep their interest, curiosity, learning, desire, and effort at a high level.

- Those who are closely interested in animals and plants and have experiences in the nature may be more sensitive for the environmental problems in their future lives than those who do not have such kind of experiences.

- Activities such as growing plants or feeding animals should be encouraged in their learning environment.

\section{ACKNOWLEDGMENTS}

The authors would like to thank Prof. Dr. Tuncay Dirmenci and Prof. Dr. Serdar Sak, Balıkesir University, Dr. Abdulmüttalip Akkaya and Şenay Uçar, Ministry of National Education, Turkey, are appreciated for providing valuable feedback for the classification of animals and plants. We would like to thank gifted and talented students for their participation in this study.

\section{REFERENCES}

Baykoç, D.N., \& Kurt, Z.Ş. (2004). Orientation of Gifted and Talented Children and their Families in Infancy and Preschool Period. Gifted and Talented Proceedings. Istanbul: Children Foundation Publications, I. Turkey Gifted and Talented Congress Publication Series, 2, 393-400.

Büyüköztürk, Ş., Kılıç, Ç.E., Akgün, Ö.E., Karadeniz, Ş., \& Demirel, F. (2013). Bilimsel Araştırma Yöntemleri [Scientific Research Methods]. $14^{\text {th }}$ ed. Ankara: Pegem Academy Publishing.

Çepni, S., Gökdere, M., \& Küçük, M. (2002). Zihinsel Alanda Üstün
Yetenekli Öğrencilere Yönelik Purdue Modeline Dayalı fen Alanında Örnek Etkinlik Geliştirme. [Developing Sample Activities based on Purdue Model in the Field of Science for Mentally Gifted Students]. V. Ulusal Fen Bilimleri ve Matematik Eğitimi Kongresi, ODTÜ Kültür ve Kongre Merkezi, Ankara. (The 5th National Science and Mathematics Education Congress, METU Culture and Convention Center, Ankara.)

Emre, F.E. (2012), İlköğretim Öğrencilerinin Bitki ve Hayvanlara Karşı Ilgileri ve bu Ilgileri Belirleyen Uyarıcı Faktörler. [Primary Education Students' Interest in Animals and Plants and the Stimulating Factors that Determine this Interest]. Hacettepe Üniversitesi Sosyal Bilimler Enstitüsü. İlköğretim Anabilim Dalı. Yüksek Lisans Tezi, Ankara. (Hacettepe University Institute of Social Sciences, Department of Primary Education, Master Thesis, Ankara.)

Emre, F.E., \& Erten, S. (2012). İlköğretim öğrencilerinin bitki ve hayvanlara karşı ilgileri ve bu ilgileri belirleyen uyarıcı faktörler. [Primary education students' interest in animals and plants and the stimulating factors that determine this interest]. Ulusal Fen Bilimleri ve Matematik Eğitimi Kongresi, Niğde. (The $10^{\text {th }}$ National Science and Mathematics Education Congress, Niğde).

Erten, S. (2008). İlk ve ortaöğretim öğrencilerinin insan biyolojisi konularına yönelik ilgileri. [Primary and secondary education students' interests in human biology.] Hacettepe Üniversitesi Eğitim Fakültesi Dergisi (Hacettepe University Journal of Education), 35, 135-147.

Freeman, J. (1999). Teaching gifted pupils. Journal of Biological Education, 34(4), 185-190.

Gökdere, M. (2004). Üstün Yeteneklilerin fen Bilimleri Öğretmenlerinin Eğitimine Yönelik bir Model Geliştirme Çalıșmast. [A Model Development Study for the Education of the Science Teachers of Gifted Students]. Karadeniz Teknik Üniversitesi Fen Bilimleri Enstitüsü, Yayınlanmamış Doktora Tezi, Trabzon. (Karadeniz Technical University Institute of Science, Unpublished PhD Thesis, Trabzon.)

Gökdere, M., \& Ayvac1, H.Ş. (2004). Determination of primary teacher's knowledge level about giftedness concept. Ondokuz Mayls Üniversitesi Eğitim Fakültesi Dergisi(Ondokuz Mayis University Journal of Faculty of Education, 18, 17-26.

Gökdere, M., \& Küçük, M. (2003). Science education of gifted students at intellectual area: Acase for science artcenters. Kuram ve Uygulamada Eğitim Bilimleri (Educational Sciences: Theory and Practice), 3(1), 118-124.

Hirca, N. (2012). Perceptions of science and art centers' teachers about a nature and science camp designed for gifted and talented students. Turkish Journal of Giftedness and Education, 2(1), 60-76.

Hidi, S., \& Renninger, K.A. (2006). The four-phase model of interest development. Educational Psychologist, 4(2), 111-127.

Kontaş, H. (2010). Learning strategies of gifted elementary students. Elementary Education Online, 9(3), 1148-1158.

Kontaş, H., \& Yağc1, E. (2016). BİLSEM öğretmenlerinin program geliştirme ihtiyaçlarına ilişkin geliştirilen programın etkinliliği [The effectiveness of the in-service training program developed on the basis of the needs of the teachers of science and art centers in the area of curriculum development]. Abant İzzet Baysal Üniversitesi Eğitim Fakültesi Dergisi (Abant İzzet Baysal University Journal of Faculty of Education), 16(3), 902-923.

Korkmaz, H., \& Kaptan, F. (2001). Project-based learning aproach in science education. Hacettepe Üniversitesi Ĕgitim Fakültesi Dergisi (Hacettepe University Journal of Education), 20, 193-200.

Kök, B. (2012). Üstün Zekâlı ve Yetenekli Öğrencilerde Farklılaştırılmış Geometri Ögretiminin Yaratıcılı̆̆a, Uzamsal Yeteneğe ve Bașarlya Etkisi [The Influence of Differentiated Geometry Teaching on Creativity, Spatial Ability and Success in Gifted and Talented Students]. Istanbul: Doctoral Thesis, Institute of Social Sciences of Istanbul University, Special Education Department.

Laçin, Ş.C., \& Nuhoğlu, H. (2009). Fen konularına yönelik geçerli ve güvenilir bir ilgi ölçeği geliştirme. [Developing a reliable and valid interest inventory for science subjects.] Sakarya Üniversitesi Eğitim Fakültesi Dergisi (Sakarya University Journal of Educational Faculty), 18, 28-41.

MEB Bilim ve Sanat Merkezleri Yönergesi [MoNE Science and Art Center Guideline] (2015). Milli Eğitim Bakanlığı Bilim ve Sanat Merkezleri Yönergesi [Ministry of National Education, Science and Art Center Guideline]. T.C. Milli Eğitim Bakanlığı Özel Eğitim ve Rehberlik Hizmetleri Genel Müdürlüğ̈̈, Available from: http://orgm.meb.gov.tr/ meb_iys_dosyalar/2015_09/18101802_bilimvesanatmerkezleriynergesi. 
pdf. [Last accessed on 2018 Mar 14].

MEB Biyoloji Dersi Öğretim Programı [MoNE Biology Course Curriculum]. (2013). Güncellenen Ortaögretim Biyoloji Dersi (9, 10, 11 ve 12. Siniflar) Öğretim Programi. [Updated Secondary Education Biology Courses (9, 10, 11 and 12 th Grades) Course Curriculum]. Available from: http://www.ttkb.meb.gov.tr/www/guncellenen-ogretimprogramlari/icerik/151. [Last accessed on 2018 Mar 14].

Miles, M.B., \& Huberman, A.M. (1994). Qualitative Data Analysis. $2^{\text {nd }}$ ed. Newbury Park, CA: Sage.

Ngoi, M., \& Vondracek, M. (2004). Working with gifted science students in a public high school environment: One school's approach. Journal of Advanced Academics, 15(4), 141-147.

Oluk, S. (2009). İlköğretim 7. sınıf öğrencilerinde yılanlarla ilgili alternatif kavramlar ve yaygın inanıșlar. [ $7^{\text {th }}$ grade students' alternative conceptions and widespread beliefs about snakes]. Ekoloji (Ecology), 18(70), 47-56.

Özarslan, M. (2015). Proje Paydașlarının Bilsem Biyoloji Projeleri Hakkindaki Düşünceleri ve bu Projelerin Üstün Zekalı ve Yetenekli Öğrencilerin Biyoloji Öğrenmeve Yönelik Motivasyonları ile Bilimsel Tutumlarina Etkisi. [The Thoughts of Project Partners on BILSEM Biology Projects and the Effect of these Projects on the Motivations of Gifted and Talented Students Towards Learning Biology and their Scientific Attitudes]. Balıkesir Üniversitesi Fen Bilimleri Enstitüsü, Yayınlanmamış Doktora Tezi, Balıkesir. (Balikesir University Institute of Science, Unpublished $\mathrm{PhD}$ Thesis, Balikesir.)

Özdinç, F., \& Altun, A. (2014). Factors effecting information technology teacher trainees' programming process. Elementary Education Online, 13(4), 1531-1541.

Özel, M., Sürücü, A., \& Bilen, K. (2013). İlköğretim öğrencilerinin bitkilere yönelik tutumları. [Primary school students' attitudes toward plants]. Pamukkale Üniversitesi Eğitim Fakültesi Dergisi (Pamukkale University Journal of Education), 34(2), 119-132.

Palanc1, M. (2004). Reality-Based Model of School Guidance and Counseling Services to Meet the Needs of Gifted Students. Gifted Proceedings, Istanbul: Children Foundation Press, Publication Series I. Turkey Gifted Congress.

Powers, E.A. (2008). The use of independent study as a viable differentiation technique for gifted learners in the regular classroom. Gifted Child
Today, 31(3), 57-65.

Prokop, P., \& Tunnicliffe, S.D. (2008). "Disgusting” animals: Primary school children's attitudes and myths of bats and spiders. Eurasia Journal of Mathematics, Science and Technology Education, 4(2), 87-97.

Prokop, P., Kubiatko, M., \& Fancovicová, J. (2008). Slovakian pupils' knowledge of, and attitudes toward, birds. Anthrozoös, 21(3), 221-235.

Sak, U. (2012). Üstün Zekalılar: Özellikleri, Tanllanmalarl, Eğitimleri. [The Gifted: Characteristics, Identification and Education]. Ankara: Maya Academy Publishing.

Strauss, A., \& Corbin, J.M. (1990). Basics of Qualitative Research: Grounded Theory Procedures and Techniques. Newbury Park, CA: Sage Publications, Inc.

Taber, K.S. (2010). Challenging gifted learners: General principles for science educators; and exemplification in the context of teaching chemistry. Science Education International, 21(1), 5-30.

Trna, J. (2014). IBSE and gifted students. Science Education International, 25(1), 19-28

Türnüklü, A. (2000). Eğitim bilim araştırmalarında etkin olarak kullanılabilecek nitel bir araştırma tekniği: Görüşme. Kuram ve Uygulamada Eğitim Yönetimi, 24, 543-559.

Uzun, M. (2004). A Gifted Children's Handbook. Istanbul: Children's Foundation Publications.

Van Tassel-Baska, J., \& Stambaugh, T. (2009). Üstün Zekâll ve Yetenekli Öğrenciler İçin Eğitim Programı [A Training Program for Gifted and Talented Students]. (Çev. Ed: Serap Emir) İstanbul: Bilimsel Açılım Akademik Yayınc1lik. pp. 315-333.

Yetkin, Y. (1998). Biyoloji eğitimi ile sağlanan davranış değişikliklerinin insanın yücelişi ve dünya barışına katkısı. [The influence of biology education on attitudes to humanity and world peace]. Turkish Journal of Biology, 22, 347-367.

Yıldırım, A., \& Şimşek, H. (2008). Nitel Araştırma Yöntemleri [Qualitative Research Methods]. $7^{\text {th }}$ ed. Ankara: Seçkin Yayıncılık.

Yılmaz, H., \& Türkmen, H. (2007). An accurate picture of what is currently happening in Turkish science classrooms. Science Education International, 18(4), 255-266. 


\section{APPENDIXES}

\begin{tabular}{|c|c|c|c|}
\hline Kingdom & Animal and plant genus and species & Kingdom & Animal and plant genus and species \\
\hline Animal Kingdom & & & Chameleon \\
\hline Invertebrates & & & Caspian turtle \\
\hline Annelids & Earthworm & Amphibians & Agile frog \\
\hline Mollusca & Snail & & Uludağ frog \\
\hline \multirow[t]{7}{*}{ Arthropoda } & Anatolian yellow scorpion & & Mertensiella luschani \\
\hline & Black scorpion & Birds & Starling \\
\hline & Crab & & Curlew \\
\hline & Spider & & Partridge \\
\hline & Pill bug & & Duck \\
\hline & Butterfly & Plant Kingdom & \\
\hline & Centipede & Cryptogams & Fern \\
\hline \multirow[t]{2}{*}{ Echinodermata } & Sea urchin & & Lungwort \\
\hline & Starfish & & Mosses \\
\hline Vertebrates & & & Marsh horsetail \\
\hline \multirow[t]{2}{*}{ Chondrichthyes } & Shark & Phanerogams & \\
\hline & Ray & Gymnosperms & Pine tree \\
\hline \multirow[t]{2}{*}{ Osteichthyes } & Scorpion fish & & Fir \\
\hline & Bonito & & Picea \\
\hline \multirow[t]{6}{*}{ Reptiles } & Blindworm & Angiosperms & Chamomile \\
\hline & Balkan green lizard & & Dill \\
\hline & Anatolian lizard & & Tangerine \\
\hline & Caspian whip snake & & Rubber tree plant \\
\hline & Whip snake & & Corn poppy \\
\hline & Dwarf snake & & Snapdragon \\
\hline
\end{tabular}

\section{Appendix 2}

\section{Questionnaire of gifted and talented students' views about biology activities at the science and art center}

1. Which animal genus and species have you examined so far in biology activities in the SAC?

2. Which animal genus and species out of the ones you have examined so far in biology activities aroused your interest the most? (Rank from the one which interested you most to least)

3. Which characteristics of the animal genus and species you have examined so far in biology activities aroused your interest? Explain why.

4. Which animal genus and species would you prefer to examine in future biology activities?

5. Which plant genus and species have you examined so far in biology activities in the SAC?

6. Which plant genus and species out of the ones you have examined so far in biology activities aroused your interest the most? (Rank from the one which interested you most to least)

7. Which characteristics of the plant genus and species you have examined so far in biology activities aroused your interest? Explain why.

8. Which plant genus and species would you prefer to examine in future biology activities?

9. What are your feelings and views about biology activities in the SAC where plant and animal genus and species are examined?

10. What is the effect of the biology activities in the SAC where plant and animal genus and species are examined on your feelings and views about biology? Please explain. 